\title{
Development of Anastrepha fraterculus (Wiedemann, 1830) (Diptera: Tephritidae) in Different Host Fruits
}

\author{
R. S. Boldo ${ }^{1}$, A. Kovaleski ${ }^{2}$, J. M. Rosa ${ }^{1}$, M. I. C. Boff ${ }^{1} \&$ C. R. Franco ${ }^{1}$ \\ ${ }^{1}$ College of Agriculture and Veterinary, Santa Catarina State University, Lages, Brazil \\ ${ }^{2}$ Brazilian Agricultural Research Corporation, Embrapa, Vacaria, Brazil \\ Correspondence: Joatan Machado da Rosa, College of Agriculture and Veterinary, Santa Catarina State \\ University, Lages, Brazil. Luiz de Camões, 2090, Lages, SC, Brazil. Tel: 55-493-289-9100. E-mail: \\ joatanmachado@gmail.com
}

Received: March 1, 2019

Accepted: April 8, $2019 \quad$ Online Published: June 15, 2019

doi:10.5539/jas.v11n8p273

URL: https://doi.org/10.5539/jas.v11n8p273

\begin{abstract}
The objective of this work was to determine the biological characteristics of South American fruit fly Anastrepha fraterculus (Wiedemann, 1830) (Diptera: Tephritidae) using three fruit hosts. Mature fruits of cherry (Eugenia involucrata DC. (Myrtaceae) $(\mathrm{n}=200)$, guabiroba (Campomanesia xanthocarpa (Mart.) O. Berg. (Myrtaceae) $(\mathrm{n}=200)$ and apple Malus domestica Borkh. variety "Gala" (Rosaceae) $(\mathrm{n}=100)$ were placed separately in plastic cages. These fruits were exposed to A. fraterculus for four hours for oviposition. On a daily basis, the resulting larvae and the pupa were separated. Studies on fertility and longevity used 25 pairs of adults that emerged from these fruits. A. fraterculus completed its biological cycle in all fruits tested. The period of development from egg to adult was shorter in fruits of C. xanthocarpa (25.9 days) and E. involucrata (28.6 days) than in those of $M$. domestica (34.7 days). The pre-oviposition period was shorter in adults, which emerged from fruits of $C$. xanthocarpa (9.9 days). The results show the importance of native host fruits for population growth of $A$. fraterculus, and probably, for host availability of larvae of $A$. fraterculus for natural and applied biological control in the Southern Cone of South America region.
\end{abstract}

Keywords: South American fruit fly, native fruits, myrtaceae, rosaceae

\section{Introduction}

Temperate fruit farming accounts for approximately $37 \%$ of the total revenue from fruit exports in Brazil, hence it favors the country's trade balance (Fachinello, Pasa, Schmtiz, \& Betemps, 2011). In the extreme south of Brazil, the states of Rio Grande do Sul and Santa Catarina account for about $72 \%$ of such production, and they grow grapes, apples, peaches, persimmons, figs, pears and quinces, especially. In recent years, apple has gained prominence in the world scenario, mainly because Brazil has become a self-sufficient country in apple production as well as an exporter of this fruit (Fachinello et al., 2011).

One of the main problems about the production of apples and other temperate fruits in the South America is yield losses, which are caused by infestation by fruit fly species belonging to the family Tephritidae (Kovaleski, Sugayama, Uramoto, \& Malavasi, 2000; Nunes, Müller, Gonçalves, Garcia, Costa, \& Nava, 2012; Rosa, Arioli, Santos, Menezes-Netto, \& Botton, 2017). In the Southern Brazil, the predominant species is the South American fruit fly Anastrepha fraterculus (Wiedemann) (Diptera: Tephritidae) (Kovaleski et al., 2000; Garcia, Campos, \& Corseuil, 2003; Garcia \& Norrbon, 2011). Similarly, temperate fruit trees grown in Argentina, Uruguay and Peru are attacked by this fruit fly species (Jaldo, Gramajo, \& Willink, 2001). These insects also represent an impediment to fruit crop diversification plans by local governments and severely limit fresh fruit exports due to quarantine restrictions imposed by importing countries such as the USA and Japan (Ovruski, Schliserman, \& Aluja, 2004).

In Brazil, 110 host plants of $A$. fraterculus have already been recorded, especially Myrtaceae, Rutaceae and Rosaceae, which represent 64\% of the known host species (Salles, 1995; Zucchi, 2008). Species of Myrtaceae, e.g., cherry of Rio Grande Eugenia involucrata DC, guabiroba Campomanesia xanthocarpa (Mart.) O. Berg, Acca sellowiana (O. Berg) Burret and cattley guava Psidium cattleianum Sabine are considered to be the main 
host plants of A. fraterculus between the months of December and May (Salles, 1995; Kovaleski, 1997; Garcia \& Norrbon, 2011).

The quality of available food is one of the main reasons for insect abundance (Ovruski et al., 2004). The species or cultivar of the available fruit tree does not always foster the development of A. fraterculus. Although this insect causes damage to some cultivars of grapes (Vitis spp.) and apples (Malus domestica Borkh.), the larvae do not always complete their biological cycle (Santos, Redaelli, Sant'ana, \& Hickel, 2015; Zart, Fernandes, \& Botton, 2010).

According to Bisognin et al. (2013), longevity and fecundity of A. fraterculus females was greater when larval development occurred in native fruits of $P$. cattleianum and surinam cherry Eugenia uniflora L. when compared with exotic fruits of blueberry Vaccinium ashei Reade and blackberry Rubus spp. The highest infestation rates by fruit flies usually occur in native fruits. For this reason, control measures should also be adopted for these hosts, in addition to management practices currently applied in commercial orchards (Salles, 1995; Kovaleski, 1997; Bisognin et al., 2013). Thus, this work determined the biological characteristics of $A$. fraterculus in fruits of native host plants (E. involucrata and C. xanthocarpa) and in M. domestica ('Gala' variety).

\section{Methods}

\subsection{Rearing of Anastrepha fraterculus}

The experiments were conducted with adults of the 52th generation of A. fraterculus. Rearing began after collection of C. xanthocarpa and A. sellowiana fruits infested by fruit flies in the town of Vacaria, state of Rio Grande do Sul, in 2011.

The adults were reared in plastic cages $(92 \times 60 \times 55 \mathrm{~cm})$ with front and top openings covered with voile fabric. They were fed a diet based on coarse sugar, beer yeast and soybean at a 3:1:1 ratio and water, separately.

The eggs were removed with the aid of "oviposition panels" made with plastic Petri dishes $(15 \mathrm{~cm}$ in diameter), whose bottom was covered with voile fabric and a black silicone film, filled with distilled water (FAO/IAEA, 1999). This panel was kept for 24 hours in the upper part of the rearing cages, and the eggs were then fed on an artificial diet composed of wheat bran $(60 \mathrm{~g})$, maize flour $(240 \mathrm{~g})$, sugar $(30 \mathrm{~g})$ and beer yeast $(50 \mathrm{~g})$. The pupa were placed on plastic trays containing sterilized fine-textured vermiculite until emergence of adult insects.

\subsection{Biology of Anastrepha fraterculus Under Laboratory Conditions}

In the field, in areas of remnant natural vegetation, green fruits of E. involucrata and C. xanthocarpa were protected with nonwoven fabric bags to avoid natural infestation by fruit flies until the harvest period. To start the experiment, 200 fruits of each species were collected from the host plant at the time of maturation. In a 'Gala' M. domestica orchard grown under a conventional system at the Experimental Station of Temperate Fruit Farming from Vacaria, RS (Brazil), 100 fruits were collected and stored in a cold chamber for 30 days prior to the conduction of the experiment.

The fruits of each fruit tree were placed all at once in plastic cages for infestation by $A$. fraterculus. A ratio of two pairs of A. fraterculus was used per fruit of E. involucrata and C. xanthocarpa. For infestation of M. domestica, four pairs were used per fruit. These ratios of flies per fruit were determined in preliminary tests, based on fruit size, to avoid excessive oviposition on fruits, which could compromise food availability to the larvae. The fruits remained exposed to flies for four hours for oviposition in a climate-controlled room at $25 \pm 1{ }^{\circ} \mathrm{C}, 70 \pm 10 \% \mathrm{RH}$ and $14: 10$ (L:D) photoperiod.

After oviposition, the fruits were individually placed in transparent $250 \mathrm{~mL}$ plastic cups covered with a layer of vermiculite at the bottom. The cups were topped with voile fabric. On a daily basis, 5 days after fruit exposure for oviposition, the larvae and the pupa were separately placed in tissue culture dishes containing vermiculite moistened with distilled water until emergence of adults; they were kept in a climate-controlled room at $25 \pm 1{ }^{\circ} \mathrm{C}$, $70 \pm 10 \% \mathrm{RH}$ and 14:10 (L:D) photoperiod.

After emergence of adults, 25 males and females with less than 24 hours of age, collected from each host fruit, were paired using cages made out of $250 \mathrm{~mL}$ transparent plastic cups covered with voile fabric. The solid diet and the water were separately provided inside the cage on a regular basis. On a daily basis, an "oviposition panel" (15 cm diameter) was placed at the top of each cage to collect the eggs.

During the immature stage, the following parameters were evaluated: duration of the egg-pupa period; duration of pupal stage; duration of the egg-adult period; number of pupa per fruit; weight of pupa at 10 days of age, and pupal viability. Weight was taken using a $0.001 \mathrm{~g}$ precision analytical scale. 
In adulthood, calculations were made to determine sex ratio [Sex ratio $=$ Number of females/(Number of females + Number of males)]; duration of pre-oviposition, oviposition and post-oviposition periods; daily and total fecundity rate; egg viability and longevity of females and males. Fertility was evaluated with 20 eggs from each pair per treatment, collected as of the second day of oviposition and, subsequently, every two days. The eggs were removed from the "oviposition panels" with a Pasteur pipette. After that, the eggs were placed on a strip of black voile fabric on filter paper in Petri dishes, covered with a damp cloth (Spontex Resistance ${ }^{\mathbb{R}}$ ) at the bottom to prevent the egg dehydration. These eggs were kept in a climate-controlled room under the same above-mentioned physical conditions. After incubation for 48 hours, egg viability was evaluated by inspection of physical damage to the shell or presence of holes as a result of larval hatching.

\subsection{Data Analysis}

The experiment was conducted in a completely randomized design and the data were submitted to analysis of variance. The means were compared by Tukey's test at $5 \%$ probability. For calculation of pupal viability, the repetitions that had only one pupa per fruit were excluded to avoid outliers. The analyses were performed using the SAS Software ${ }^{\mathrm{TM}}$, version 9.0 (SAS, 2002).

\section{Results and Discussion}

During the development of the immature stages of $A$. fraterculus, differences were noted for duration of the following periods: egg-pupa $(\mathrm{F}=416.11 ; \mathrm{DF}=2,271 ; \mathrm{P}<0.0001)$ and egg-adult $(\mathrm{F}=380.79 ; \mathrm{DF}=2,261 ; \mathrm{P}<$ 0.0001 ) between host fruits (Table 1). The developmental period of the immature stage of A. fraterculus in host fruits of E. involucrata and C. xanthocarpa (Myrtaceae) was shorter when compared with development in fruits of 'Gala' M. domestica (Rosaceae) (Table 1).

Table 1. Mean values ( \pm SEM) of the biological characteristics of Anastrepha fraterculus (Wiedemann, 1830) (Diptera: Tephritidae) in host fruits infested in the laboratory $\left(25 \pm 1{ }^{\circ} \mathrm{C}, 70 \pm 10 \% \mathrm{RH}\right.$ and 14:10 (L:D) photoperiod)

\begin{tabular}{llll}
\hline Biological characteristics & Eugenia involucrata & Campomanesia xanthocarpa & Malus domestica \\
\hline Egg-pupa period (days) & $11.1 \pm 0.06 \mathrm{~b}$ & $11.5 \pm 0.08 \mathrm{~b}$ & $18.4 \pm 0.32 \mathrm{a}$ \\
& $(9-14)^{1}[491]^{2}$ & $(8-14)[332]$ & $(12-25)[84]$ \\
\hline Pupal stage (days) & $17.5 \pm 0.07 \mathrm{a}$ & $13.7 \pm 0.05 \mathrm{c}$ & $16.4 \pm 0.10 \mathrm{~b}$ \\
& $(13-20)[394]$ & $(12-17)[244]$ & $(14-20)[77]$ \\
\hline Egg-adult period (days) & $28.6 \pm 0.06 \mathrm{~b}$ & $25.9 \pm 0.09 \mathrm{c}$ & $34.7 \pm 0.30 \mathrm{a}$ \\
& $(25-30)[394]$ & $(23-28)[244]$ & $(29-41)[77]$ \\
\hline Pupal weight (mg) & $13.4 \pm 0.19 \mathrm{a}$ & $11.8 \pm 0.21 \mathrm{~b}$ & $8.3 \pm 0.25 \mathrm{c}$ \\
& $(3-19)[491]$ & $(1-19)[313]$ & $(3-14)[84]$ \\
\hline Pupal viability (\%) & $80.1 \pm 2.30 \mathrm{~ns}$ & $77.1 \pm 2.15$ & $90.2 \pm 2.64$ \\
\hline Sex ratio & $(0-100)[491]$ & $(0-100)[313]$ & $(0-100)[84]$ \\
\hline
\end{tabular}

Note. Means followed by the same letter, in the row, do not differ by Tukey's test $(\mathrm{P}>0.05)$. ns $=$ non-significant.

${ }^{1}$ Range of variation; ${ }^{2}$ Number of observations.

The pupa from the C. xanthocarpa fruits had the fastest development (13.7 days). By contrast, those pupa originated from $E$. involucrata had the longest duration (17.5 days); while pupa from $M$. domestica completed development in an intermediary period (16.4 days) $(\mathrm{F}=347.73 ; \mathrm{DF}=2,262 ; \mathrm{P}<0.0001)$ (Table 1). The pupa from the fruits of $M$. domestica had the lowest weight compared to pupa from the fruits of $C$. xanthocarpa and $E$. involucrata $(\mathrm{F}=48.32, \mathrm{DF}=2,285 ; \mathrm{P}<0.0001)$. However, these host fruits did not influence pupal viability ( $\mathrm{F}$ $=2.79 ; \mathrm{DF}=2,232 ; \mathrm{P}=0.0637)$ and sex ratio $(\mathrm{F}=1.00 ; \mathrm{DF}=2,260 ; \mathrm{P}=0.3696)($ Table 1$)$.

With respect to duration of the egg-adult period, the fruits of $C$. xanthocarpa and E. involucrata led to faster development of $A$. fraterculus, with a significant difference between the treatments $(\mathrm{F}=380.79 ; \mathrm{DF}=2,261 ; \mathrm{P}<$ 0.0001 ). The adults from fruits of $M$. domestica emerged at eight and six days after emergence of adults from fruits of C. xanthocarpa and E. involucrata, respectively (Table 1). 
In the adult stage, there was greater longevity of males when reared on E. involucrata and $M$. domestica, but this result did not differ significantly from that of $C$. xanthocarpa $(\mathrm{F}=3.15 ; \mathrm{DF}=2,72 ; \mathrm{P}=0.0489)$ (Table 2). For females, the greatest longevity was found in insects from fruits of cherry of the Rio Grande $(\mathrm{F}=6.44 ; \mathrm{DF}=2,72$; $\mathrm{P}=0.0027$ ) (Table 2). For the reproductive period of females, differences were found only between insects from C. xanthocarpa, which had the shortest pre-oviposition period. The first oviposition took place as of the eighth day, with an average of 9.9 days; this result differed from that of the other hosts $(\mathrm{F}=12.63$, DF $=2,54 ; \mathrm{P}<$ 0.0001) (Table 2). Thus, evaluation of fruit host quality can also be based on the pre-oviposition period. When oviposition occurs earlier, there is increased opportunity for insects to leave their offspring in new hosts.

Table 2. Mean values ( \pm SEM) of the biological characteristics of adults of Anastrepha fraterculus (Wiedemann, 1830) (Diptera: Tephritidae) from larvae which developed in host fruits infested in the laboratory $\left(25 \pm 1{ }^{\circ} \mathrm{C}\right.$, $70 \pm 10 \%$ RH and 14:10 (L:D) photoperiod)

\begin{tabular}{llll}
\hline Biological characteristics & Eugenia involucrata & Campomanesia xanthocarpa & Malus domestica \\
\hline Pre-oviposition (days) & $12.8 \pm 0.34 \mathrm{~b}$ & $9.9 \pm 0.70 \mathrm{a}$ & $11.5 \pm 6.00 \mathrm{~b}$ \\
& $(11-15)^{1}$ & $(8-16)$ & $(9-15)$ \\
\hline Oviposition period (days) & $28.5 \pm 18.81 \mathrm{~ns}$ & $18.6 \pm 2.56$ & $27.1 \pm 19.81$ \\
& $(3-54)$ & $(3-36)$ & $(6-56)$ \\
\hline Post-oviposition (days) & $21.8 \pm 5.26 \mathrm{~ns}$ & $15.4 \pm 2.59$ & $16.1 \pm 3.66$ \\
& $(3-66)$ & $(2-49)$ & $(1-58)$ \\
\hline Daily fecundity rate & $11.4 \pm 1.77 \mathrm{~b}$ & $20.7 \pm 2.26 \mathrm{a}$ & $18.7 \pm 2.38 \mathrm{ab}$ \\
& $(0.43-24.54)$ & $(1.00-33.00)$ & $(0.29-40.00)$ \\
\hline Total fecundity rate & $300.3 \pm 51.28 \mathrm{~ns}$ & $401.3 \pm 61.08$ & $479.7 \pm 94.86$ \\
& $(10-767)$ & $(11-841)$ & $(9-1,326)$ \\
\hline Egg viability (\%) & $85.9 \pm 1.06 \mathrm{~ns}$ & $85.4 \pm 1.06$ & $91.9 \pm 1.30$ \\
& $(48.75-94.24)$ & $(41.40-87.00)$ & $(42.50-93.75)$ \\
\hline Longevity of males (days) & $65.8 \pm 6.04 \mathrm{a}$ & $48.8 \pm 1.35 \mathrm{~b}$ & $56.9 \pm 5.43 \mathrm{ab}$ \\
& $(25-115)$ & $(34-62)$ & $(20-95)$ \\
\hline Longevity of females (days) & $63.8 \pm 5.19 \mathrm{a}$ & $42.7 \pm 2.46 \mathrm{~b}$ & $48.2 \pm 4.78 \mathrm{~b}$ \\
& $(26-102)$ & $(14-64)$ & $(14-4)$ \\
\hline
\end{tabular}

Note. Means followed by the same letter, in the row, do not differ by Tukey's test $(\mathrm{P}>0.05)$. ns $=$ non-significant.

${ }^{1}$ Range of variation.

The three fruit species (E. involucrata, C. xanthocarpa and 'Gala' M. domestica) can be considered as hosts because they enabled the development of $A$. fraterculus. However, variation in food may explain the differences found in the biological characteristics of the South American fruit fly among the host fruits that were evaluated in the present study.

When a diet is inadequate for larval development, it may influence not only duration and viability of the immature stage, but also the weight of pupa and the size of adults. Consequently, longevity and fecundity are also affected (Cresoni-Pereira \& Zucoloto, 2009; Nunes et al., 2013). Based on this assumption, the greatest reproductive success of $A$. fraterculus should have been found in adults from larvae that fed on fruits of $E$. involucrata or C. xanthocarpa in comparison to M. domestica, because the pupa showed significantly lower weight in this latter host. However, there were no differences in these characteristics: oviposition period $(\mathrm{F}=$ 3.08; $\mathrm{DF}=2,55 ; \mathrm{P}=0.0538)$, in total fecundity $(\mathrm{F}=1.61 ; \mathrm{DF}=2,54 ; \mathrm{P}=0.2101)$, and egg viability $(\mathrm{F}=0.63$; $\mathrm{DF}=2,40 ; \mathrm{P}=0.5384)$. Although $M$. domestica can be considered as an alternative host, as it is less favorable to the development of the immature stages of $A$. fraterculus, it enabled enough nutritional resources to ensure the generation of new offspring (Table 2).

An exception was daily fertility rate, which was higher for insects from fruits of C. xanthocarpa; it was even higher than oviposition rates of females from E. involucrata, but it as high in $M$. domestica $(\mathrm{F}=5.07 ; \mathrm{DF}=2,54$; $\mathrm{P}=0.0096$ ). This parameter can explain the influence of the host fruit on the daily pace of oviposition. In fruits of C. xanthocarpa, approximately 50\% of the eggs were produced between 16 and 17 days after emergence of 
adults, while in fruits of E. involucrata and M. domestica, egg production occurred between 31 and 32 days and 26 and 27 days, respectively (Figure 1).

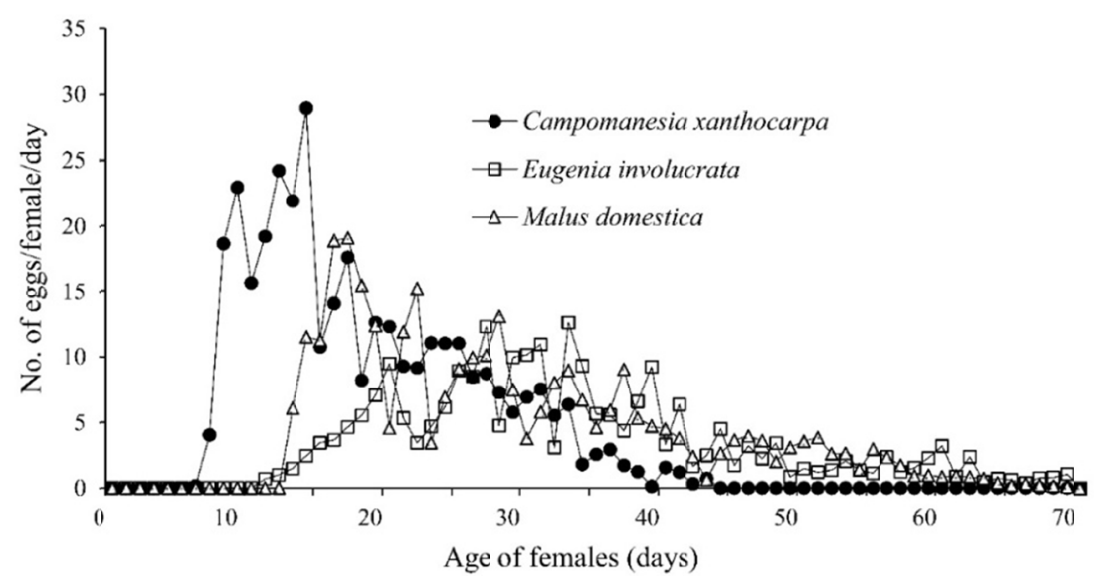

Figure 1. Daily pace of oviposition of Anastrepha fraterculus (Wiedemann, 1830) (Diptera: Tephritidae) from larvae that developed in host fruits infested in the laboratory $\left(25 \pm 1{ }^{\circ} \mathrm{C}, 70 \pm 10 \% \mathrm{RH}\right.$ and 14:10 (L:D) photoperiod)

The fruits of 'Gala' $M$. domestica were also considered less favorable to the development of the Mediterranean fruit fly, Ceratitis capitata Wiedemann, 1824 (Diptera: Tephritidae) compared with fruits of peach (Prunus persica L.) Stokes because the egg-adult period was longer in larvae from fruits of $M$. domestica trees (Zanardi, Nava, Botton, Grützmacher, Machota Júnior, \& Bisognin, 2011).

The behavior of the larvae of $A$. fraterculus was observed in some fruits of $M$. domestica. In the pulp of those fruits, one could see tunnels or larvae near the surface of the skin or inside the fruit; tunnels had been formed in several directions. In other situations, the larvae approached the epidermis, pierced the skin and went back into the fruit. This behavior may also be indicative of less acceptance of food by the larvae. Although mobility in the immature stage of holometabolic insects is restricted, the larvae of fruit flies are capable of selecting the most appropriate food or food portions to their development, under laboratory conditions (Crestoni-Pereira \& Zucoloto, 2009; Schwarz, Durisko, \& Dukas, 2014). However, the search for a safe place for development is a predominant behavior in comparison with selection of the ideal diet (Schwarz, Durisko, \& Dukas, 2014).

Importantly, among cultivars of the same host, there can be differences in susceptibility to infestation by fruit flies. According to Santos et al. (2015), mature fruits of $M$. domestica cultivar from the M-11/00 selection resulted in the development of a greater number of larvae+pupa per fruit (4.9), under natural infestation conditions, compared with the cultivar Catarina (0.30). This difference in the host quality of $M$. domestica can also be influenced by the maturation stage of the fruits. In mature fruits, a greater number of larvae+pupa was developed in comparison to immature fruits: 4.9 and 1.6, respectively (Santos et al., 2015).

Host fruits can be classified into multipliers, which allow a significant increase in the insect population, or alternative, which are those infested occasionally or that multiply a small quantity of insects (Salles, 1995). Thus, the effect of host fruits on the larval development of $A$. fraterculus may explain the infestation rates observed in the field. The results of the present study reinforce the hypothesis that the fruits of native species, such as $E$. involucrata and C. xanthocarpa, are important multipliers of $A$. fraterculus. Moreover, the fruits of 'Gala' $M$. domestica represent an alternative host for this fruit fly species (Salles, 1995; Kovaleski, 1997; Garcia \& Norrbon, 2011).

The development of $A$. fraterculus in fruits of native species, such as $P$. cattleianum and E. uniflora, allowed a longer oviposition period and greater longevity when compared with the development in alternative hosts, $e . g$., $V$. ashei and Rubus spp. (Bisognin et al., 2013). Under field conditions, this adaptive advantage led to more intense infestation by A. fraterculus in P. cattleianum and E. uniflora (Bisognin, Nava, Diez-Rodríguez, Valgas, Garcia, Krolow, \& Antunes, 2015).

In the south region of Brazil, E. involucrata is considered to be the first native host plant to fructify after the winter, i.e., between September and November. Hypothetically, adults that emerge from these fruits will infest 
fruits of C. xanthocarpa, and the maturation period occurs between November, December and early January. After that, $M$. domestica fruits will be infested as of December and in periods next to the harvest (Kovaleski 1997; Nora \& Hickel, 2006; Rosa et al., 2017). In newly formed M. domestica fruits, with $1.5 \mathrm{~cm}$ in diameter or bigger, injuries are due to oviposition puncture, which causes the fruits to become deformed and fall off. However, in fully developed fruits, larvae develop by feeding on fruit pulp (Salles, 1995; Nora e Hickel, 2006).

Currently, biological control is a very important control method in fruit farming in Brazil for management of fruit flies (Garcia \& Ricalde, 2013). There may be up to $30 \%$ of natural parasitism, mainly by native parasitoids of the family Braconidae. The highest rate of parasitism is usually found in native fruits, e.g., P. cattleianum, E. uniflora and E. involucrata (Nunes et al., 2012). The presence of native fruits which favor the multiplication of fruit flies enhance the biological characteristics of $A$. fraterculus, hence these fruits will probably be important to maintain and establish natural and applied biological control programs for fruit fly larvae in temperate fruit farming in southern Brazil and in other Latin American countries.

\section{Conclusion}

The fruits of C. xanthocarpa (guabiroba), E. involucrata (cereja-do-rio-grande, cherry of Rio Grande) and $M$. domestica ('Gala' apple) enable full development of $A$. fraterculus. The period of post-embryonic development of A. fraterculus is faster in fruits of C. xanthocarpa and E. involucrata than in fruits of 'Gala' M. domestica. The pre-oviposition period of $A$. fraterculus is shorter in fruits of C. xanthocarpa than in fruits of E. involucrata and 'Gala' M. domestica.

\section{References}

Bisognin, M., Nava, D. E., Diez-Rodríguez, G. I., Valgas, R. A., Garcia, M. S., Krolow, A. C., \& Antunes, L. E. C. (2015). Development of Anastrepha fraterculus (Diptera: Tephritidae) related to the phenology of blueberry, blackberry, strawberry guava, surinam cherry fruits. Journal of Economic Entomology, 108(1), 192-200. https://doi.org/10.1093/jee/tou002

Bisognin, M., Nava, D. E., Lisbôa, H., Bisognin, A. Z., Garcia, M. S., Valgas, R. A., ... Antunes, L. E. C. (2013). Biologia da mosca-das-frutas-sul-americana em frutos de mirtilo, amoreira-preta, araçazeiro e pitangueira. Pesquisa Agropecuária Brasileira, 48(2), 141-147. https://doi.org/10.1590/S0100-204X2013000200003

Cresoni-Pereira, C., \& Zucoloto, F. S. (2009). Moscas-das-frutas (Diptera). In A. Panizzi, \& J. R. P. Parra (Eds.), Bioecologia e nutrição de insetos: base para o manejo integrado de pragas (pp. 733-766). Brasília, BR: Embrapa.

Fachinello, J. C., Pasa, M. S., Schmtiz, J. D., \& Betemps, D. L. (2011). Situação e perspectivas da fruticultura de clima temperado no Brasil. Revista Brasileira de Fruticultura, 33(1), 109-120. https://doi.org/10.1590/ S0100-29452011000500014

FAO/IAEA. (1999). The South American fruit fly, Anastrepha fraterculus (Wied.); Advances in artificial rearing, taxonomic status and biological studies. Vienna, AU: International Atomic Energy Agency.

Garcia, F. R. M., \& Ricalde, M. P. (2013). Augmentative Biological Control Using Parasitoids for Fruit Fly Management in Brazil. Insects, 4(1), 55-70. https://doi.org/10.3390/insects4010055

Garcia, F. R. M., Campos, J. V., \& Corseuil, E. (2003). Análise faunística de espécies de mosca-das-frutas (Diptera: Tephritidae) na região do Oeste de Santa Catarina. Neotropical Entomology, 32(3), 421-426. https://doi.org/10.1590/S1519-566X2003000300006

Garcia, F. R. M., \& Norrbom, A. L. (2011). Tephritoid flies (Diptera, Tephritoidea) and their plant hosts from the state of Santa Catarina in southern Brazil. Florida Entomologist, 94(2), 151-157. https://doi.org/ 10.1653/024.094.0205

Jaldo, H. E., Gramajo, M. C., \& Willink, E. (2001). Mass rearing of Anastrepha fraterculus (Diptera: Tephritidae): A preliminary strategy. Florida Entomologist, 48(4), 716-718. https://doi.org/10.2307/3496407

Kovaleski, A. (1997). Processos adaptativos na colonização da maçã (Malus domestica) por Anastrepha fraterculus (Wied.) (Diptera: Tephritidae) na região de Vacaria, RS (PhD Thesis, University of São Paulo, Brazil).

Kovaleski, A., Sugayama, R. L., Uramoto, K., \& Malavasi, A. (2000). In A. Malavasi, \& R. A. Zucchi (Org.), Moscas-das-frutas de importância econômica no Brasil: Conhecimento básico e aplicado (pp. 285-290). Ribeirão Preto, SP: Holos. 
Nora, I., \& Hickel, E. R. (2006). Pragas da macieira. In Epagri (Ed.), A cultura da macieira (pp. 463-498). Florianópolis, SC: Epagri.

Nunes, A. M., Müller, F. A., Gonçalves, R. S., Garcia, M. S., Costa, V. A., \& Nava, D. E. (2012). Moscas frugívoras e seus parasitoides nos municípios de Pelotas e Capão do Leão, Rio Grande do Sul, Brasil. Ciência Rural, 42(1), 6-12. https://doi.org/10.1590/S0103-84782012000100002

Nunes, A. M., Costa, K. Z., Faggioni, K. M., Costa, M. L. Z., Gonçalves, R. S., Walder, J. M. M., ... Nava, D. E. (2013). Dietas artificiais para a criação de larvas e adultos da mosca-das-frutas sul-americana. Pesquisa Agropecuária Brasileira, 48(10), 1309-1314. https://doi.org/10.1590/S0100-204X2013001000001

Ovruski, S. M., Schliserman, P., \& Aluja, M. (2004). Indigenous parasitoids (Hymenoptera) attacking Anastrepha fraterculus and Ceratitis capitata (Diptera: Tephritidae) in native and exotic host plants in Northwestern Argentina. Biological Control, 29(1), 43-57. https://doi.org/10.1016/S1049-9644(03)00127-0

Panizzi, A., \& Parra, J. R. P. (2009). Bioecologia e nutrição de insetos: Base para o manejo integrado de pragas. Brasília, BR: Embrapa.

Rosa, J. M. da., Arioli, C. J., Santos, J. P., Menezes-Netto, A. C., \& Botton, M. (2017). Evaluation of Food Lures for Capture and Monitoring of Anastrepha fraterculus (Diptera: Tephritidae) on Temperate Fruit Trees. Journal of Economic Entomology, 110(3), 995-1001. https://doi.org/10.1093/jee/tox084

Salles, L. A. B. (1995). Bioecologia e controle da mosca-das-frutas sul-americana. Pelotas, RS: Embrapa Clima Temperado.

Santos, J. P. dos., Redaelli, L. R., Sant'ana, J., \& Hickel, E. R. (2015). Suscetibilidade de genótipos de macieira a Anastrepha fraterculus (Diptera: Tephritidae) em diferentes condições de infestação. Revista Brasileira de Fruticultura, 37(1), 90-95. https://doi.org/10.1590/0100-2945-050/14

SAS Institute. (2002). SAS User's Guide: Statistics. Software Version 9.0. Cary, NC, USA.

Schwarz, S., Durisko, Z., \& Dukas, R. (2014). Food selection in larval fruit flies: Dynamics and effects on larval development. Naturwissenschaften, 101(1), 61-68. https://doi.org/10.1007/s00114-013-1129-z

Zanardi, O. Z., Nava, D. E., Botton, M., Grützmacher, A. D., Machota Júnior, R., \& Bisognin, M. (2011). Desenvolvimento e reprodução da mosca-do-mediterrâneo em caquizeiro, macieira, pessegueiro e videira. Pesquisa Agropecuária Brasileira, 46(7), 682-688. https://doi.org/10.1590/S0100-204X2011000700002

Zart, M., Fernandes, O., \& Botton, M. (2010). Biology and fertility life table of the South American fruit fly Anastrepha fraterculus on grape. Bulletin of Insectology, 63(1), 237-242.

Zucchi, R. A. (2008). Fruit flies in Brazil-Anastrepha species, their host plants and parasitoids. Retrieved from http://www.lea.esalq.usp.br/anastrepha

\section{Copyrights}

Copyright for this article is retained by the author(s), with first publication rights granted to the journal.

This is an open-access article distributed under the terms and conditions of the Creative Commons Attribution license (http://creativecommons.org/licenses/by/4.0/). 